\title{
Enhanced Autophagy and Reduced Expression of Cathepsin D Are Related to Autophagic Cell Death in Epstein-Barr Virus-Associated Nasal Natural Killer/T-Cell Lymphomas: An Immunohistochemical Analysis of Beclin-1, LC3, Mitochondria (AE-1), and Cathepsin D in Nasopharyngeal Lymphomas
}

\author{
Kazuhisa Hasui ${ }^{1,4}$, Jia Wang ${ }^{1,5}$, Xinshan $\mathrm{Jia}^{2}$, Masashi Tanaka ${ }^{3}$, Taku Nagai ${ }^{3}$, \\ Takami Matsuyama ${ }^{3}$ and Yoshito Eizuru ${ }^{1}$ \\ ${ }^{1}$ Division of Persistent and Oncogenic Viruses, Center for Chronic Viral Diseases, Kagoshima University Graduate School of \\ Medical and Dental Sciences, Kagoshima, Japan, 'Department of Pathology, China Medical University, Shenyang, China, \\ ${ }^{3}$ Division of Immunology, Kagoshima University Graduate School of Medical and Dental Sciences, Kagoshima, Japan, \\ ${ }^{4}$ Present address: Division of Immunology, Kagoshima University Graduate School of Medical and Dental Sciences, \\ Kagoshima, Japan and ${ }^{5}$ Present address: Department of Molecular Genetics, Medical Institute of Bioregulation, \\ Kyushu University Graduate School of Medicine, Fukuoka, Japan
}

Received August 11,2010; accepted April 7, 2011; published online June 3, 2011

\begin{abstract}
This study investigated autophagy in 37 cases of nasopharyngeal lymphomas including 23 nasal natural killer (NK)/T-cell lymphomas (NKTCL), 3 cytotoxic T-cell lymphomas (cytotoxic$\mathrm{TML}$ ) and 9 B-cell lymphomas (BML) by means of antigen-retrieval immunohistochemistry of beclin-1, LC3, mitochondria (AE-1) and cathepsin D. Peculiar necrosis was noted in EBV+ lymphomas comprising 21 NKTCL, 2 cytotoxic-TML and 1 BML. Lymphomas without peculiar necrosis showed high expression of beclin-1, macrogranular cytoplasmal stain of LC3 with sporadic nuclear stain, a hallmark of autophagic cell death (ACD), some aggregated mitochondria and high expression of cathepsin D, suggesting a state of growth with enhanced autophagy with sporadic ACD. EBV ${ }^{+}$NKTCL with the peculiar necrosis, showed significantly low level of macrogranular staining of LC3, aggregated mitochondria and low expression of cathepsin $D$ in the cellular areas when degenerative lymphoma cells showed decreased beclin-1, significantly advanced LC3-labeled autophagy, residual aggregated mitochondria and significantly reduced expression of cathepsin D, suggesting advanced autophagy with regional ACD. Consequently it was suggested that enhanced autophagy and reduced expression of lysosomal enzymes induced regional ACD under EBV infection in NKTCL.
\end{abstract}

Key words: nasopharyngeal lymphoma, NKT-cell lymphoma nasal type, Epstein-Barr virus (EBV), autophagy, autophagic cell death, antigen retrieval immunohistochemistry (beclin-1, LC3, mitochondria (AE-1) and cathepsin D)

\section{Introduction}

Nasal natural killer (NK)/T-cell lymphoma (NKTCL), is the dominant type of nasopharyngeal lymphoma in Asia

Correspondence to: Dr. Kazuhisa Hasui, Division of Immunology, Kagoshima University Graduate School of Medical and Dental Sciences, Sakuragaoka 8-35-1, Kagoshima 890-8544, Japan. E-mail: anahasui@m3.kufm.kagoshima-u.ac.jp and South America, especially in China but rarely in Japan. NKTCL cells show diffuse proliferation and an immunological phenotype of either $\mathrm{CD} 3 \varepsilon^{+} \mathrm{TIA}^{+}{ }^{+} \mathrm{CD} 56^{+} \mathrm{NK} / \mathrm{T}$ cells or $\mathrm{CD} 3 \varepsilon^{+} \mathrm{TIA}^{+}{ }^{+} \mathrm{CD} 56^{-}$cytotoxic T-cells [14]. NKTCL is usually Epstein-Barr virus (EBV)-associated; shows signals of in-situ hybridization (ISH) of EBV-encoded small RNA1 (EBER-1) in their nuclei [9]; and associates with CD204 ${ }^{+}$ macrophages to form a meshwork of their cytoplasmal processes [32]. Besides, NKTCL shows also peculiar necro- 
sis that was first named rhinitis gangrenosa [20]. Peculiar necrosis has been suggested to be due to autophagy under EBV infection when neoplastic expression of survivin $[1,11,31]$ suppressed apoptosis as judged by labeling with anti-cleaved caspase-3 antibody [32].

Autophagic cell death (ACD) [17] is a lysosomerelated programmed cell death (PCD) called as type II PCD. Autophagy is modulated by target of rapamycin (Tor) that initiates autophagy through Atg1-related complex formation probably at the endoplasmic reticulum [12] under homeostatic mass control, physiological stimuli such as starvation and proliferation, pharmacological agonists such as rapamycin, and immunological stimuli [3, 4, 27]. Next, beclin-1 forms a complex with type III phosphatidylinositol 3-kinase (PI3K), Vps34 and UV-irradiation-resistanceassociated gene (UVRAG) [25], and begins the vesicle nucleation forming the autophagophore. Atg5-Atg12 system including Atg7, Atg3, Atg10, and Atg16L lipidates LC3-I to LC3-II (membrane-bound form of LC3), forming autophagophore with LC3-II that engulfs altered organella such as mitochondria. Next, GTPase, Rab7-Rab5 system, maturates the autophagophore into an autophagosome. The UVRAG-HOPS complex then induces fusion of the autophagosome with endosomes and lysosomes [25] including cathepsin D and also has ATP-dependent $\mathrm{H}^{+}$pump. The engulfed organella and molecules are finally degraded in the auto(phago)lysosome, where molecules with antigenicity are recruited to the endosomes for MHC class II antigen presentation, while molecules recognized by Toll-like receptors (TLRs) evoke anti- and pro-innate immunity [3, 4, 27]. The contents of the autolysosome are then either excreted or remain as a residual body.

However, the relationship between autophagy and ACD has yet to be elucidated clearly [24]. Uchiyama [30] reported a close relationship between the activation of cathepsin D and the ACD of neurons. NKTCL often shows cellular, degenerative and necrotic areas in its lesions and its peculiar necrosis shows aggregated and densely LC3labeled nucleus-like cell debris (a hallmark of ACD) [32]. Mitochondria are representative target organella of the macroautophagy that is involved with ACD and are found in cytoplasm, autophagosomes and autolysosomes. Cathepsin $\mathrm{D}$ is a lysosomal enzyme digesting molecules and organella in autolysosomes. Therefore, their immunohistochemical detection with beclin-1 in the nucleation of autophagophore and LC3 in the autophagosome and autolysosome was expected to be informative for the processes of the enhanced autophagy leading to ACD in NKTCL cells.

In this study we mainly investigated autophagy-related molecules, beclin-1 and LC3, and aggregated mitochondria and cathepsin $\mathrm{D}$ in nasopharyngeal lymphomas [32] by means of immunohistochemistry (IHC). It was elucidated that EBV-induced enhanced autophagy and reduced expression of cathepsin D could explain the peculiar necrosis in EBV-associated NKTCL.

\section{Materials and Methods}

\section{Cases examined}

Archival paraffin specimens of 134 cases of nasopharyngeal lymphoma from northeast China were reexamined [32] and among them 37 cases showing areas of lymphoma tissue free from obvious degenerative changes were selected for this study. In the clinicopathological information of patients, only age, sex and biopsy site were available. This study was performed with the approval of the Ethics Committee for epidemiological studies in Kagoshima University Graduate School of Medical and Dental Sciences and of the Ethics Committee for international co-operative studies in China Medical University.

Based on the typing of lymphomas and the detection of EBV latent infection by means of ISH of EBER-1 given below, these lymphomas comprised 28 cases of T/NK-cell neoplasm (TML) and 9 cases of B-cell neoplasm (BML). The 28 TML comprised 23 NKTCL, 3 cytotoxic T-cell lymphoma (cytotoxic-TML) and 2 polymorphous reticulosis (PR)/early NKTCL (E-NKTCL) (Table 1). These cases of TML were included in so-called nasal NKTCL in WHO classification [14]. As shown in Table 1, there were two cases of $\mathrm{EBV}^{-}$NKTCL when the other NKTCLs were $\mathrm{EBV}^{+}$cases and three of 9 cases of $\mathrm{BML}$ were $\mathrm{EBV}^{+}$cases. TML and NKTCL dominated in males and in the nasal

Table 1. Clinicopathological information and status of Epstein-Barr virus infection in the cases examined

\begin{tabular}{|c|c|c|c|c|c|c|c|}
\hline & \multirow[b]{2}{*}{ No. } & \multirow[b]{2}{*}{$\mathrm{M} / \mathrm{F}$} & \multicolumn{2}{|c|}{ Age (yrs) } & \multicolumn{3}{|c|}{$\begin{array}{l}\text { Site (EBV infection status; } \\
\left.\mathrm{EBV}^{-}: \mathrm{EBV}^{+/-}: \mathrm{EBV}^{+}\right)\end{array}$} \\
\hline & & & Mean & Range & Nasal cavity & Pharynx & Unknown \\
\hline T/NK-cell neoplasm (TML) & 28 & 19:9 & 44.5 & $18-70$ & $19(2: 0: 17)$ & $6(0: 2: 5)$ & $3(0: 0: 3)$ \\
\hline NK/T-cell lymphoma (NKTCL) & 23 & $17: 6$ & 43.0 & $20-56$ & $17(2: 0: 15)$ & $3(0: 0: 3)$ & $3(0: 0: 3)$ \\
\hline Cytotoxic T-cell lymphoma (Cytotoxic TML) & 3 & $2: 1$ & 47.3 & $18-67$ & $1(0: 0: 1)$ & $2(0: 1: 1)$ & 0 \\
\hline Polymorphous reticulosis (PR)/Early NKTCL (E-NKTCL) & 2 & $0: 2$ & 57.0 & 29,65 & $1(0: 0: 1)$ & $1(0: 1: 0)$ & 0 \\
\hline B-cell neoplasm (BML) & 9 & $3: 6$ & 52.4 & $13-84$ & $3(0: 0: 3)$ & $5(3: 2: 0)$ & $1(0: 1: 0)$ \\
\hline
\end{tabular}

So-called nasal NKTCL comprises NKTCL, Cytotoxic TML and PR/E-NKTCL.

EBV infection status: $\mathrm{EBV}^{-}$: no infection in lymphoma cells; $\mathrm{EBV}^{+/}$: incomplete neoplastic expansion of EBV latent infection in lymphoma cells; $\mathrm{EBV}^{+}$: complete neoplastic expansion of EBV latent infection in lymphoma cells. 
cavity and BML in the pharynx. EBV-associated lymphomas were frequently seen in the nasal cavity, as reported previously [32].

\section{Typing of lymphomas}

The lymphoma cases were mostly re-categorized according to the WHO classification [14] based on the immunological phenotype of lymphoma cells determined by means of IHC. Antibodies (CD3e, CD5, CD79a, TIA1 and CD56) listed in Table 2 were employed for determining the phenotype of lymphoma cells. After deparaffinization, endogenous peroxidase inactivation by incubating sections in $0.3 \% \mathrm{H}_{2} \mathrm{O}_{2}$ methanol solution for 30 min was followed by three rinses in phosphate buffer saline (PBS), pH 7.2. Antigen retrieval (AR) was performed by heating sections in citrate buffer (Target retrieval solution, S1699, Dako), $\mathrm{pH}$ 6 , for $5 \mathrm{~min}$ at $121^{\circ} \mathrm{C}$ in an autoclave (KTS-2322, ALP Co. Ltd., Tokyo, Japan), followed by three rinses in PBS. After being treated with blocking of non-specific stain (Protein blocking, X0909, Dako), primary antibody reaction with each antibody diluted at the ratio listed in Table 2 in the antibody dilution solution (Dako REAL ${ }^{\mathrm{TM}}$, S2022) was performed for $1 \mathrm{hr}$. The reacted primary antibody was labeled with a polymer reagent (ChemMate Envision, K5027, Dako) for $30 \mathrm{~min}$, and was visualized by means of $\mathrm{H}_{2} \mathrm{O}_{2}$ diaminobenzidine (DAB) reaction (DAB+, Liquid, K3468, Dako) for $10 \mathrm{~min}$ (the polymer method in Table 2). These procedures were performed by an autostainer (Autostainer, Dako) with rinsing buffer warmed to $35^{\circ} \mathrm{C}$. The sections removed from the autostainer were dehydrated and were mounted in a plastic medium.

Based on IHC of CD3e, CD5, CD79a, TIA1 and CD56, the lymphoma with $\mathrm{CD} 3 \varepsilon^{+} \mathrm{CD}^{+/-} \mathrm{CD} 79 \mathrm{a}^{-} \mathrm{TIA}^{+/-}$ $\mathrm{D}^{2} 6^{+/}$phenotype was TML when that with $\mathrm{CD} 3 \varepsilon^{-} \mathrm{CD}^{+/-}$ $\mathrm{CD} 79 \mathrm{a}^{+} \mathrm{TIA1}^{-} \mathrm{CD}^{-}$phenotype was BML. In TML the case with $\mathrm{CD} 3 \varepsilon^{+} \mathrm{CD}^{+/-} \mathrm{CD} 79 \mathrm{a}^{-} \mathrm{TIA}^{+} \mathrm{CD}^{-}$phenotype was cytotoxic TML and that with $\mathrm{CD} 3 \varepsilon^{+/-} \mathrm{CD}^{+/-} \mathrm{CD}^{+} \mathrm{a}^{-}$ $\mathrm{TIA}^{+} \mathrm{CD}^{+} 6^{+}$phenotype was NKTCL. Further categorization of lymphomas was performed according to the WHO classification [14].

\section{ISH of EBER-1}

Association of EBV infection was examined by ISH of EBER-1 according to the method reported previously [29]. Briefly, after deparaffinization, sections were digested with proteinase $\mathrm{K}$ at $37^{\circ} \mathrm{C}$ for $30 \mathrm{~min}$, dehydrated, and dried. Hybridization with digoxigenin-labeled probes was then performed at $37^{\circ} \mathrm{C}$ more than three hr. The hybridized probes were visualized by means of alkaline phosphataselabeled anti-digoxigenin antibody and a colorimetric alkaline phosphatase-nitro blue tetrazolium chloride/5bromo-4-chloro-3-indolyl phosphate, toluidine salt activity reaction (DIG-nucleic acid detection kit, 1175041, Roche, Mannheim, Germany). After nuclear counterstaining with methyl green, sections were dehydrated and mounted in plastic medium. An EBV-positive gastric adenocarcinoma, simultaneously stained by the same method, was used as positive control.

EBV latent infection detected by EBER-1 ISH was evaluated as no EBV latent infection in lymphoma cells $\left(\mathrm{EBV}^{-}\right)$with or without rare probably small memory B cells infected latently by EBV, incomplete neoplastic expansion EBV $\left({ }^{+/}\right)$, and complete neoplastic expansion $\left(\mathrm{EBV}^{+}\right)$, as shown in Figure 1.

\section{Immunohistochemistry (IHC) of apoptosis and autophagy-related molecules}

Cleaved caspase-3 is key molecule in irreversible apoptosis when survivin [1, 11, 31] suppresses cleaved caspase- 3 and these two molecules can be detected in

Table 2. Antibodies used and antigen retrieval/detection methods

\begin{tabular}{|c|c|c|c|c|c|}
\hline Antibody & Specificity or function & Clone/Source & Dilution & $\begin{array}{l}\text { Antigen } \\
\text { retrieval }\end{array}$ & $\begin{array}{l}\text { Detection } \\
\text { method }\end{array}$ \\
\hline $\mathrm{CD} 3 \varepsilon$ & $\mathrm{T}$ cells, NK/T cells & NCL-CD3-PS1/Vision Biosystems & $1: 100$ & Heat* & Polymer \\
\hline CD5 & $\mathrm{T}$ cells & NCL-CD5-4C7/Vision Biosystems & $1: 50$ & Heat* & Polymer \\
\hline CD79a & B cells & M7050/Dako & $1: 200$ & Heat* & Polymer \\
\hline TIA1 & T cells, NK/T cells (Cytotoxic granules) & TIA1/Coulter Immunology & $1: 500$ & Heat* & Polymer \\
\hline CD56 & NK/T cells, plasma cells & NCL-CD56-IB6/Vision Biosystems & $1: 50$ & Heat* & Polymer \\
\hline Cleaved caspase- 3 & Irreversible apoptosis & 5A1 Asp175/Cell Signaling Co. & $1: 200$ & Heat** & Polymer \\
\hline Survivin & Inhibitor of apoptosis & ab469/Abcam & $1: 500$ & Heat** & Polymer \\
\hline Beclin-1 & Autophagic vesicle nucleation & Sc-11427/Santa Cruz & $1: 50$ & Enzyme & Supersensitive \\
\hline $\mathrm{LC}-3$ & Autophagic vesicle elongation & PM036/MBL & $1: 1000$ & Heat** & Polymer \\
\hline AE-1 & Mitochondria & AE-1/Leinco Technologie Inc. & $1: 50$ & Heat** & Polymer \\
\hline Cathepsin D & Lysosomal enzyme & NCL-CDm (C5)/Vision Biosystems & $1: 100$ & Heat** & Polymer \\
\hline
\end{tabular}

Antigen retrieval methods: Heat*; Sections were heated in citrate buffer $\mathrm{pH} 6$ (Target retrieval solution, $\mathrm{S} 1699$, Dako) for 5 min at $121^{\circ} \mathrm{C}$ in an autoclave. Heat**; Sections in the citrate buffer (Diva Decloaker, Biocare Medical) for 5 min at $121^{\circ} \mathrm{C}$ in an autoclave. Enzymatic antigen retrieval; Sections were treated with $200 \mathrm{mg} / \mathrm{mL}$ proteinase $\mathrm{K}$ Tris buffer saline solution for 10 min at room temperature.

Detection methods: Polymer; ChemMate Envision system (K5027, Dako). Supersensitive; The polymer method (K5027, Dako) with blocking of non-specific reactions, the catalyzed reporter deposition (CARD) reaction and its detection in a catalyzed signal amplification (CSA) system with blocking diffused deposition in CARD reaction. 


\section{No EBV latent infection in lymphoma cells (EBV ${ }^{-}$)}

Incomplete neoplastic expansion of EBV latent infection $\left(\mathrm{EBV}^{+/}\right)$

\section{$\mathrm{T} \cdot \mathrm{NK}$-cell neoplasm}

(TML)

(BML)
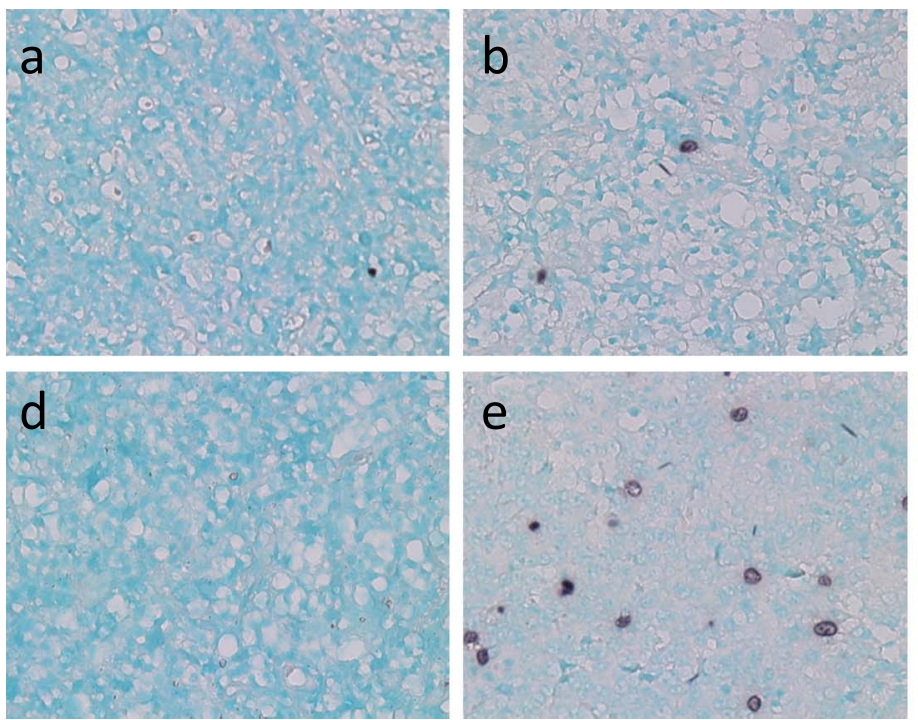

\section{Complete neoplastic expansion of EBV latent infection $\left(\mathrm{EBV}^{+}\right)$}
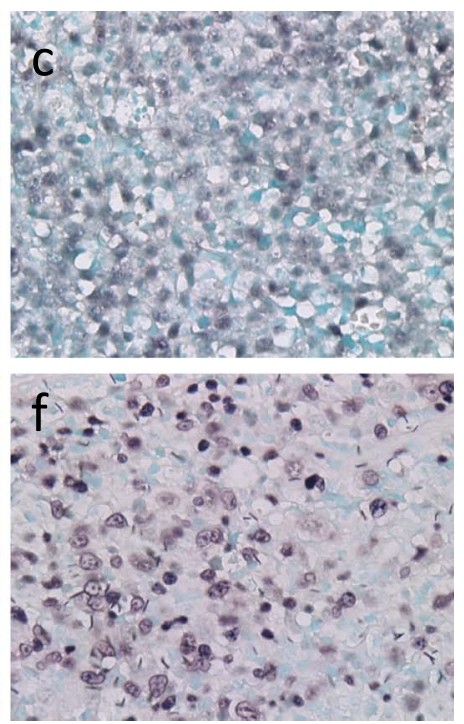

Fig. 1. Detection of EBV latent infection by means of ISH of EBER-1. The long axis of all microphotographs was $215 \mu \mathrm{m}$ long at $\times 40$ magnification. Lymphomas without EBV latent infection $\left(\mathrm{EBV}^{-}\right.$, a, d) show no or rare probably small memory B-cells infected latently by EBV. Lymphomas with EBV latent infection $\left(\mathrm{EBV}^{+}, \mathbf{c}, \mathbf{f}\right)$ show EBER-1 signals in the most lymphoma cells, suggesting complete neoplastic expansion of EBV latent infection. Lymphomas show EBER-1 signals in a few to some lymphoma cells $\left(\mathrm{EBV}^{+/-}, \mathbf{b}\right.$, e), suggesting incomplete neoplastic expansion of EBV latent infection.

archival paraffin sections by IHC [7, 8]. Cleaved caspase-3 and survivin were retrieved by heating sections in the solution (Diva Decloaker, Biocare Medical, Concord, CA, USA) independently from $\mathrm{pH}$ of the solution and were detected by the antibody and polymer method listed in Table 2 .

Beclin-1 is one of the autophagy-related molecules in the autophagic vesicle nucleation complex that was detected by means of enzymatic AR and supersensitive IHC [10, 15, 32] when beclin-1 in a complex with Bcl-2, Bcl- $\mathrm{X}_{\mathrm{L}}$ and H3-only proteins in cytoplasm would be digested in the enzymatic AR. After deparaffinization and the first endogenous peroxidase inactivation and rinse in PBS, enzymatic AR incubating sections in proteinase $\mathrm{K}(200 \mathrm{mg} / \mathrm{ml}$, No. 9033, Takara Bio Co., Otsu, Shiga, Japan) -0.05 M Tris buffer saline, $\mathrm{pH} 7.2$, solution for $10 \mathrm{~min}$ was followed by the second endogenous peroxidase inactivation in $3 \% \mathrm{H}_{2} \mathrm{O}_{2}$ PBS for $5 \mathrm{~min}$. Reacted primary antibody in the reaction for $15 \mathrm{~min}$ was labeled with a polymer reagent (ChemMate Envision, K5027, Dako) for 15 min followed by catalyzed reporter deposition amplification reaction (K1500, Dako), with pretreatment against the non-specific reaction (Protein blocking, X0909, Dako) before each process, and was visualized by means of $\mathrm{H}_{2} \mathrm{O}_{2}$-diaminobenzidine (DAB) reaction (DAB+, Liquid, K3468, Dako) for 5 min (The supersensitive method in Table 2). These procedures were performed by an autostainer with rinsing buffer warmed to $35^{\circ} \mathrm{C}[10]$. The sections removed from the autostainer were dehydrated and were mounted in a plastic medium.
LC3-I and II in the elongation of autophagosome were detected in the western blot analysis of the lyophilized cell lysate from serum starved Neuro 2A cells (supplied with 0231 s0104 from Nanotools) with anti-LC3 antibody, PM036 from MBL (Table 2) [32] and LC3-II (the membrane-bound form of LC3) was retrieved by heating sections in the solution independently from $\mathrm{pH}$ of the solution and were detected by the polymer method of PM036 in Table 2 [32].

Mitochondria are the representative organella engulfed in the autophagosome and are digested in the autolysosome. Cathepsin D is a digestion enzyme in the lysosome and autolysosome and its activation requires ATP-dependent $\mathrm{H}^{+}$ pump [2, 33]. Mitochondria and cathepsin D were retrieved by heating sections in the solution independently from $\mathrm{pH}$ of the solution and were detected by the polymer method of antibodies listed in Table 2.

The positive and negative control staining in each IHC of cleaved caspase-3, survivin, beclin-1, LC3, mitochondria (AE-1) and cathepsin D is summarized in Table 3.

The representative immunostaining of the specimens was recorded at $\times 40$ magnification by a digital microscopic camera (Fuji Digital Camera HC-300, Fujifilm, Tokyo, Japan) at cellular, degenerative and necrotic areas of the lymphoma tissue. The cellular areas of lymphoma tissue showed diffuse and adhesive growth of lymphoma cells. The peculiar necrotic areas were determined easily, showing a small number of residual cells and debris in the background of acidophilic necrotic tissue when a lesion of circulatory disturbance indicated a microthrombus in dilated blood 
Table 3. The positive and negative control in IHC of apoptosis and autophagy-related molecules employed in this study

\begin{tabular}{|c|c|c|c|}
\hline Antibody & $\begin{array}{l}\text { Positive control for IHC of each antigen in } \\
\text { ordinary human pathology specimens }\end{array}$ & $\begin{array}{l}\text { Negative control for IHC of each antigen in } \\
\text { ordinary human pathology specimens }\end{array}$ & Ref. no. \\
\hline \multirow[b]{2}{*}{ Cleaved caspase- 3} & Apoptotic cells. & Cells other than apoptotic cells. & \multirow[b]{2}{*}{15} \\
\hline & $\begin{array}{l}\text { *Positive cells were the apoptotic cells in human } \\
\text { gastric foveolar surface epithelia. }\end{array}$ & $\begin{array}{l}\text { * Negative cells were human gastric foveolar surface } \\
\text { epithelia other than apoptotic cells labeled by cleaved } \\
\text { caspase-3. }\end{array}$ & \\
\hline \multirow[b]{2}{*}{ Survivin } & $\begin{array}{l}\text { Human malignant neoplastic (cancer and lymphoma) } \\
\text { cells and stem cells. }\end{array}$ & $\begin{array}{l}\text { Normal human cells other than malignant neoplastic, } \\
\text { stem and fetal cells. }\end{array}$ & \multirow[b]{2}{*}{32} \\
\hline & $\begin{array}{l}\text { *Positive cells were nasopharyngeal lymphoma cells, } \\
\text { squamous carcinoma cells and squamous epithelial } \\
\text { (tissue) stem cells. }\end{array}$ & $\begin{array}{l}\text { *Negative cells were squamous epithelia other than } \\
\text { squamous epithelial (tissue) stem cells of which nuclei } \\
\text { were densely labeled by survivin. }\end{array}$ & \\
\hline \multirow[b]{2}{*}{ Beclin-1 } & Almost all living cells. & None. & \multirow[b]{2}{*}{15,32} \\
\hline & $\begin{array}{l}\text { *Positive cells were some gastric fundic glandular cells, } \\
\text { a few gastric glandular cells having possibly mutated } \\
\text { beclin- } 1 \text { accumulated in nuclei in the gastric fundic } \\
\text { mucosa inflamed with } H \text {. pylori infestation next to the } \\
\text { gastric cancer and most nasopharyngeal lymphoma } \\
\text { cells. }\end{array}$ & $\begin{array}{l}\text { *Negative cells were the human gastric glandular cells } \\
\text { in the gastric fundic mucosa inflamed with } H \text {. pylori } \\
\text { infestation next to the gastric cancer other than the } \\
\text { cells labeled by beclin- } 1 \text {. The degenerated lymphoma } \\
\text { cells diminished beclin-1 and could be the inner } \\
\text { negative control. }\end{array}$ & \\
\hline \multirow[b]{2}{*}{ LC3 } & Almost all living cells. & None. & \multirow[b]{2}{*}{32} \\
\hline & $\begin{array}{l}\text { *Positive cells: almost all cells in human lymph node } \\
\text { with necrotizing lymphadenitis and nasopharyngeal } \\
\text { lymphoma tissue cells. }\end{array}$ & $\begin{array}{l}\text { * Degenerated lymphoma cells among autophagic cell } \\
\text { death labeled densely by LC } 3 \text { gradually diminished } \\
\text { the immunostaining of LC } 3 \text { and could be the inner } \\
\text { negative control. }\end{array}$ & \\
\hline \multirow[b]{2}{*}{ AE-1 } & Almost all living cells. & None & \multirow[b]{2}{*}{-} \\
\hline & $\begin{array}{l}\text { * Some macrophages showed large granular } \\
\text { immunostaining of AE-1 and could be the inner } \\
\text { positive control. }\end{array}$ & $\begin{array}{l}\text { *Small lymphocytes were negative and could be the } \\
\text { inner negative control. }\end{array}$ & \\
\hline \multirow[b]{2}{*}{ Cathepsin D } & Almost all living cells & None & \multirow[b]{2}{*}{-} \\
\hline & $\begin{array}{l}\text { * Some macrophage showed dense immunostaining } \\
\text { of cathepsin D and could be the inner positive } \\
\text { control. }\end{array}$ & $\begin{array}{l}\text { * Small lymphocytes were negative and could be the } \\
\text { inner negative control. }\end{array}$ & \\
\hline
\end{tabular}

*: In IHC employed in this study.

vessels (Fig. 2). The degenerative areas were located next to the necrotic areas.

Evaluation of the immunostaining was carried out on the recorded images for reproducibility of the evaluation by Hasui K. and Wang J. according to the graded score system of beclin-1, LC3, Mitochondria (AE-1) and cathepsin D in Table 4.

The evaluated scores of the lymphomas grouped in subtypes, EBV infection and degenerative tendency were tested by Kruskal-Wallis test for more than 3 groups, MannWhitney's U test for not-corresponding data in two groups or Wilcoxon signed-ranks test for corresponding data in 2 groups by each antibody (beclin-1, LC-3, AE-1 and cathepsin D).

\section{Results}

The representative case of NKTCL showed diffuse proliferation of lymphoma cells (Fig. 3a) positive for CD3e, TIA1 (Fig. 3b), CD56 (Fig. 3c) and signals of EBER-1 (Fig. 3d), and revealed rare cleaved caspase-3 positive cells (Fig. 3e) and many cells expressing survivin densely
(Fig. 3f). In the degenerative and necrotic areas of NKTCL, there were rare cleaved caspase-3-positive cells (Fig. 3h) and residual expression of survivin was noted (Fig. 3i). The other subtypes of TML and BML also showed rare cleaved caspase-3-positive lymphoma cells when most lymphoma cells expressed survivin [32], suggesting that the PCD of lymphoma cells was not apoptosis (PCD I type) [32].

\section{Autophagy in lymphoma cells in the cellular areas (representative areas)}

TML indicated higher expression of beclin-1, lower expression of LC3, less aggregation of mitochondria and lower expression of cathepsin D than BML (Table 5).

Higher expression of beclin-1 was noted in $\mathrm{EBV}^{-}$ NKTCL than in $\mathrm{EBV}^{+}$NKTCL (Table 5, Fig. 4a1, 4a2) whereas $\mathrm{EBV}^{-} \mathrm{BML}$ revealed lower expression of beclin-1 than $\mathrm{EBV}^{+} \mathrm{BML}$ (Table 5, Fig. 5a1, 5a3). In spite of lower expression of LC3 in TML than in BML (Table 5), macrogranular dense stain of LC3 with the microgranular background stain was noted in $\mathrm{EBV}^{-}$and $\mathrm{EBV}^{+} \mathrm{NKTCL}$ (Fig. 4b1-4b3) and BMLs (Fig. 5b1, 5b3). Low aggregated mitochondria in $\mathrm{EBV}^{-}$NKTCL (Fig. 4c1) and E-NKTCL 


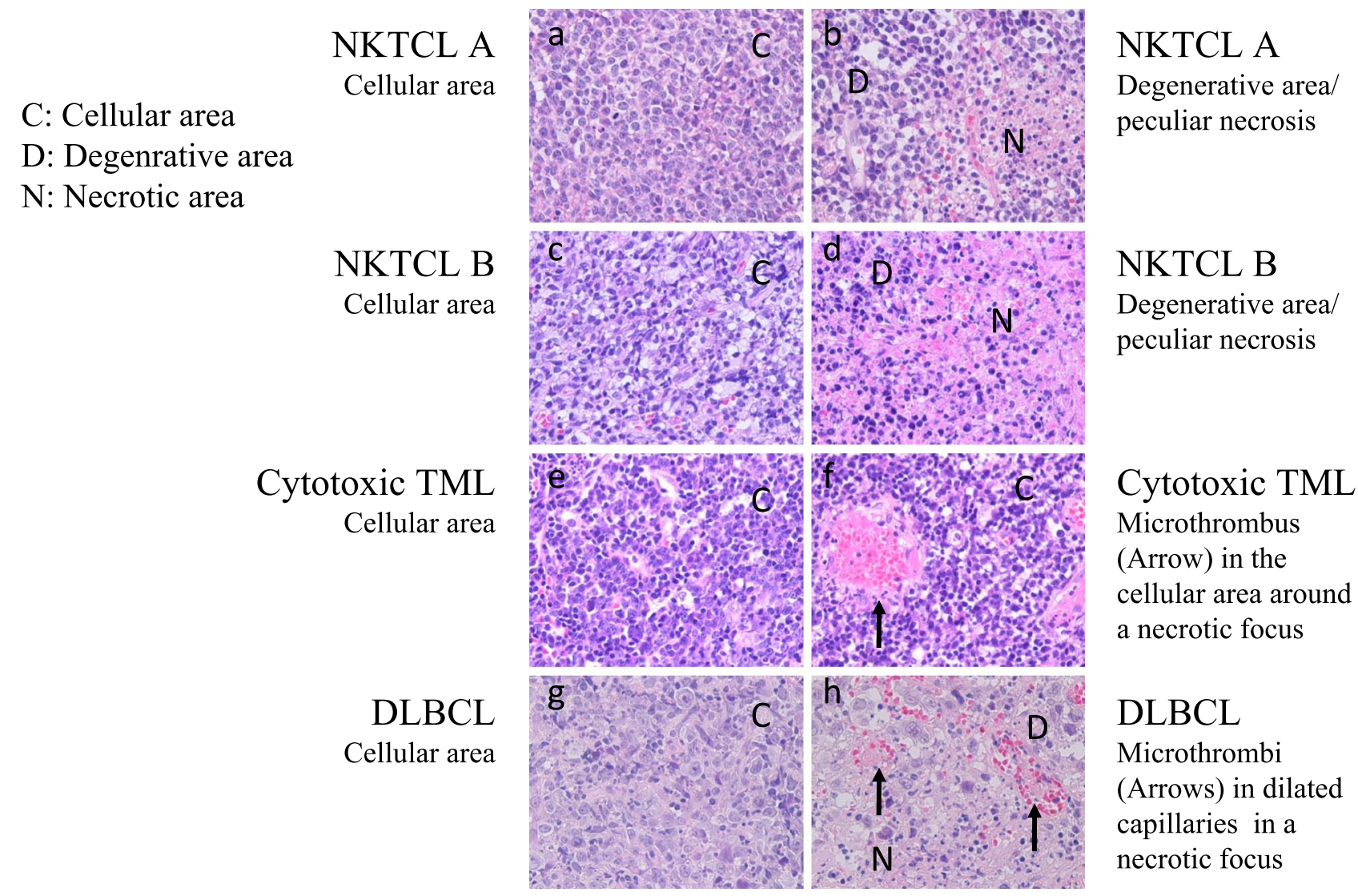

Fig. 2. Cellular, degenerative and necrotic areas in lymphoma tissue. The long axis of all the microphotographs was $215 \mu \mathrm{m}$ long at $\times 40$ magnification. The peculiar necrosis in NKTCL is seen as the ill-defined areas comprising naked nucleus-like cell debris and coagulated, acidophilic, and necrotic cells (b, d), and can be differentiated from the necrotic lesions in microinfarction revealing microthrombus in and around the necrotic areas $(\mathbf{f}, \mathbf{h})$. The degenerative areas in lymphoma tissue (D) are defined as the areas next to the necrotic areas $(\mathrm{N})$. Cellular (C), degenerative (D) and necrotic areas $(\mathrm{N})$ in the lymphoma tissue can be easily differentiated each other. Note that lymphoma cells show more adhesive growth in the cellular areas than in the degenerative ones.

reduced the mean score in TML (Table 5). Aggregated mitochondria were obvious in $\mathrm{EBV}^{+}$NKTCL (Fig. 4c2, 4c3) and BML (Fig. 5c1, 5c3). EBV infection effects were observed in the early stages of autophagy such as autophagic vesicle nucleation and elongation differently in NKTCL and BML.

Lower expression of cathepsin D in lymphoma cells was indicated in TML than in BML (Table 5). Significant lower synthesis of cathepsin D was noted in $\mathrm{EBV}^{+} \mathrm{NKTCL}$ than in cytotoxic-TML (Table 5, \#1 p=0.0387, \#2 p= 0.0396). The expression level of cathepsin $\mathrm{D}$ decreased in the order of $\mathrm{EBV}^{-} \mathrm{BML}$ (Fig. 5d1), cytotoxic-TML, $\mathrm{EBV}^{+/-}$ BML, E-NKTCL, EBV ${ }^{-}$NKTCL (Fig. 4d1), EBV ${ }^{+}$BML (Fig. 5d3) and $\mathrm{EBV}^{+}$NKTCL (Fig. 4d3) (Table 5), suggesting a different level of cathepsin $D$ expression in each subtype of lymphomas.

\section{Autophagy in lymphoma cells in the cases revealing degeneration and necrosis}

$\mathrm{EBV}^{+}$NKTCL comprised four cases free from degeneration, six cases with degeneration and 11 cases with degeneration and peculiar necrosis (Table 6). Peculiar necrosis was recognized also in two cases of CytotoxicTML and one case of $\mathrm{EBV}^{+} \mathrm{BML}$ (Table 6).

$\mathrm{EBV}^{+}$NKTCL showed no difference in the expression of beclin-1 in the cellular areas among the cases free from degeneration, those with degeneration and those with degeneration and necrosis (Table 6). However, in the $\mathrm{EBV}^{+}$ NKTCL cases with degeneration and necrosis significantly lower expression of beclin- 1 was noted in the degenerative lymphoma cells (Table 6, \#7 p=0.0041, \#8 p=0.0030, Fig. 4a4, 4a5), as well in the cases of $\mathrm{EBV}^{+}$BML (Fig. 5a3, 5a4) and of cytotoxic-TML with necrosis (Table 6) suggesting decelerated autophagic vesicle nucleation.

$\mathrm{EBV}^{+}$NKTCL cases with degeneration and necrosis showed significantly lower LC3 score in the cellular areas than those in the cellular areas of the cases free from degeneration (Fig. 4b2) and those with degeneration (Fig. 4b3, Table 6, \#1 $\mathrm{p}=0.0036, \# 2 \mathrm{p}=0.00103$, \#3 $\mathrm{p}=0.0062$ ). In the cases with degeneration and necrosis the LC3 score ascended significantly in the degenerative areas (Table 6, $\# 9 \mathrm{p}=0.0035$ ) and in the necrotic areas (Table 6, \#10 $\mathrm{p}=0.0022, \# 11 \mathrm{p}=0.0041)$, revealing nuclear stain of LC3, a hallmark of ACD [32], in the necrotic area (Fig. 4b5). The 
Table 4. Scoring system in IHC of beclin-1, LC3, mitochondria (AE-1), and cathepsin D

\begin{tabular}{|c|c|c|c|}
\hline & Score & Definition & Sample image* \\
\hline \multirow{5}{*}{ Beclin-1 } & 0 & No staining & Fig. 4 a2, a5, \\
\hline & 1 & Weak staining & $\begin{array}{l}\text { Fig. } 4 \text { a4, } \\
\text { Fig. } 5 \text { a1, a2, a4 }\end{array}$ \\
\hline & 2 & Moderate staining & $\begin{array}{l}\text { Fig. } 4 \text { a3, } \\
\text { Fig. } 5 \text { a3 }\end{array}$ \\
\hline & 3 & Strong staining & Fig. 4 al \\
\hline & 4 & Very strong staining & - \\
\hline \multirow{6}{*}{ LC3 } & 0 & No staining & - \\
\hline & 1 & $\begin{array}{l}\text { Microgranular staining in } \\
\text { cytoplasm }\end{array}$ & - \\
\hline & 2 & $\begin{array}{l}\text { Macrogranular staining in } \\
\text { background of strong micro- } \\
\text { granular staining in cytoplasm }\end{array}$ & $\begin{array}{l}\text { Fig. } 4 \text { b1, b3 } \\
\text { Fig. } 5 \text { b1, b3 }\end{array}$ \\
\hline & 3 & $\begin{array}{l}\text { Macrogranular staining in } \\
\text { background of decreased } \\
\text { microgranular staining in } \\
\text { cytoplasm }\end{array}$ & Fig. 4 b2, b4, \\
\hline & 4 & $\begin{array}{l}\text { Nuclear or perinuclear dense } \\
\text { staining in background of } \\
\text { Score } 2 \text { or } 3\end{array}$ & $\begin{array}{l}\text { Fig. } 4 \text { b5, } \\
\text { Fig. } 5 \text { b2, b4 }\end{array}$ \\
\hline & 5 & $\begin{array}{l}\text { Nuclear or perinuclear dense } \\
\text { staining without the back- } \\
\text { ground of Score } 2 \text { and } 3\end{array}$ & - \\
\hline \multirow{4}{*}{$\begin{array}{l}\text { Mitochondria } \\
(\mathrm{AE}-1)\end{array}$} & 0 & No aggregated mitochondria & - \\
\hline & 1 & $\begin{array}{l}\text { Aggregated mitochondria in a } \\
\text { few neoplastic cells }\end{array}$ & Fig. 4 c5, \\
\hline & 2 & $\begin{array}{l}\text { Aggregated mitochondria in } \\
\text { some neoplastic cells }\end{array}$ & $\begin{array}{l}\text { Fig. } 4 \mathrm{c} 1, \mathrm{c} 3 \\
\text { Fig. } 5 \mathrm{cl}\end{array}$ \\
\hline & 3 & $\begin{array}{l}\text { Aggregated mitochondria in } \\
\text { many neoplastic cells }\end{array}$ & $\begin{array}{l}\text { Fig. } 4 \mathrm{c} 2, \mathrm{c} 4 \\
\text { Fig. } 5 \mathrm{c} 2, \mathrm{c} 3, \mathrm{c} 4\end{array}$ \\
\hline \multirow{4}{*}{ Cathepsin D } & 0 & No staining in neoplastic cells & $\begin{array}{l}\text { Fig. } 4 \text { d5, } \\
\text { Fig. } 5 \text { d2, d3, d4 }\end{array}$ \\
\hline & 1 & $\begin{array}{l}\text { Weak staining in neoplastic } \\
\text { cells }\end{array}$ & Fig. 4 d3, \\
\hline & 2 & $\begin{array}{l}\text { Moderate staining in neo- } \\
\text { plastic cells }\end{array}$ & $\begin{array}{l}\text { Fig. } 4 \text { d1, d4, } \\
\text { Fig. } 5 \mathrm{~d} 1\end{array}$ \\
\hline & 3 & $\begin{array}{l}\text { Strong staining in neoplastic } \\
\text { cells }\end{array}$ & Fig. 4 d2 \\
\hline
\end{tabular}

Sample image*: Sample images $(\times 100$ oil magnification $)$ of each score of each staining in Figures 4 and 5 were indicated when evaluation of the immunostaining was carried out on the recorded images at $\times 40$ magnification for reproducibility. Score 4 immunostaining of beclin-1 was possibly detected also by the polymer method. Scores 4 and 5 immunostaining of LC3 were of ACD when the background staining diminished as residual LC3 molecules in acidophilic cell debris were gradually depleted. IHC of mitochondria (AE-1) employed detected aggregated mitochondria but not scattered mitochondria in cytoplasm such as those in small lymphocytes. Immunostaining of cathepsin D in lymphoma cells was graded when intermingling macrophages showed very strong staining.

peculiar necrosis in $\mathrm{EBV}^{+} \mathrm{NKTCL}$, cytotoxic-TML and $\mathrm{EBV}^{+}$BML (Fig. 5b4) was grouped ACD when the case free from degeneration showed sporadic distribution of ACD (Fig. 4b2).

$\mathrm{EBV}^{+}$NKTCL cells in the cellular area of the cases with degeneration and necrosis showed significantly more aggregated mitochondria (Fig. 4c3) than those in the cases free from degeneration (Fig. 4c2, Table 6, \#4 p=0.0103). Labeled aggregated mitochondria decreased significantly in the degenerative areas of the cases with degeneration (Table 6, \#6 p=0.0384) but not in the degenerative areas of the cases with degeneration and necrosis (Fig. 4c4), suggesting delayed degradation of mitochondria in the autolysosome in the cases with degeneration and necrosis. Faint stain of aggregated mitochondria remained in residual and degenerative $\mathrm{EBV}^{+} \mathrm{NKTCL}$ cells in the necrotic area (Fig. 4c5), as in the cases of $\mathrm{EBV}^{+}$BML with necrosis (Fig. 5c4), suggesting incomplete degradation of aggregated mitochondria in the autolysosome.

$\mathrm{EBV}^{+} \mathrm{NKTCL}$ cells in the cellular area of the cases with degeneration and necrosis indicated lower expression cathepsin D (Fig. 4d3) than those in the cellular area of the cases free from degeneration (Fig. 4d2) and those with degeneration (Table 6), as did $\mathrm{EBV}^{+} \mathrm{BML}$ cells in the cellular area of the cases with necrosis (Table 6, Fig. 5d3) than $\mathrm{EBV}^{-}$BML cells (Fig. 5d1). In $\mathrm{EBV}^{+}$NKTCL free from degeneration, engulfed aggregative mitochondria would be completely digested (Fig. 4c2) by a sufficient amount of cathepsin D (Fig. 4d2) under enhanced autophagy that induced sporadic ACD in the neoplastic growth (Fig. 4b2). On the other hand, in $\mathrm{EBV}^{+} \mathrm{NKTCL}$ with degeneration and necrosis, enhanced autophagy and reduced expression of cathepsin D (Fig. 4d3) induced incomplete degradation of engulfed aggregated mitochondria (Fig. 4c3) and grouped ACD in the necrosis (Fig. 4b5). One of three cases of $\mathrm{EBV}^{+} \mathrm{BML}$ indicated no expression of cathepsin D (Table 6, Fig. 5d3) and was associated with tiny ill-defined foci of necrosis with grouped ACD (Fig. 5b4).

One case of $\mathrm{EBV}^{-} \mathrm{BML}$ formed an intraepithelial microabscess filled with degenerative lymphoma cells. The $\mathrm{EBV}^{-} \mathrm{BML}$ cells in the microabscess showed faint immunostaining of beclin-1 (Fig. 5a2), some traces of ACD labeled by LC3 (Fig. 5b2), some aggregated mitochondria (Fig. 5c2) and no expression of cathepsin D (Fig. 5d2), reflecting an end state of autophagy with ACD in starvation when autophagy was active in the lymphoma cells in the cellular area (Table 6, Fig. 5a1, 5b1, 5c1 and 5d1).

\section{Discussion}

This study analyzed PCD in nasopharyngeal lymphomas by means of IHC. IHC of anti-cleaved caspase-3 antibody signaled a new age in detecting apoptosis in human pathology specimens [8]. However, nasopharyngeal lymphoma cells express survivin (inhibitor of apoptosis-1) and do not show cleaved caspase-3-positive apoptotic cells, suggesting that survivin suppresses apoptosis [32], as shown in Figure 3. This is the first immunohistochemical study to analyze autophagy on sections of archival pathology specimens of human malignant neoplastic cells that show no apoptosis. As shown in Figure 6, the targets of IHC in this study are the indicators of autophagy between the autophagy initiating stage and the lysosomal enzymes activating stage. It is well known that the PI3K-Tor path- 
The cellular areas (a to f) H.E. (a), TIA1 (b) and CD56 (d)

ISH of EBER-1 (d). cleaved caspase-3 (e) and survivin (f)

\section{The degenerative and necrotic areas ( $\mathrm{g}$ to $\mathrm{i}$ )} H.E. (g), cleaved caspase-3 (h) and survivin (i)
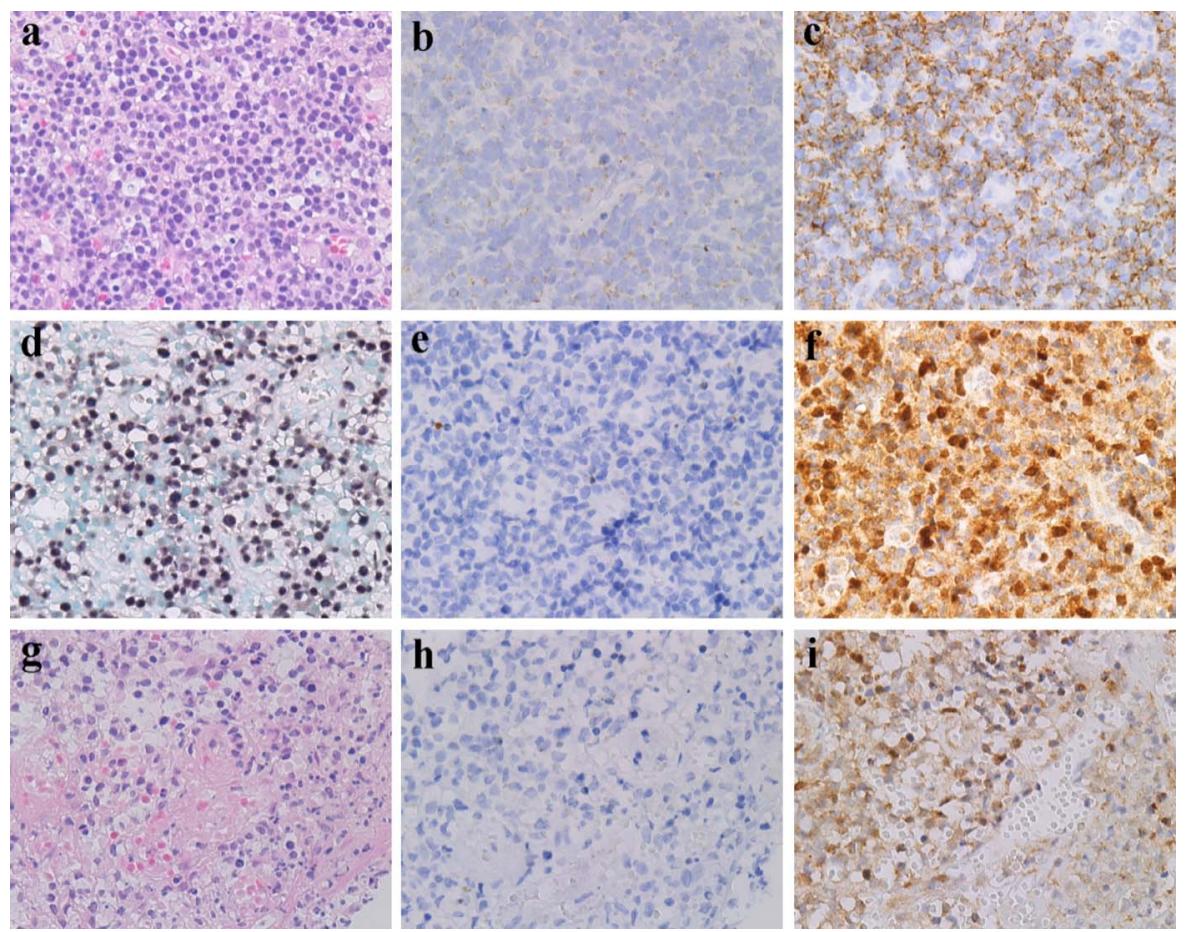

Fig. 3. A representative nasal NK/T-cell lymphoma (NKTCL). The long axis of all the microphotographs was $215 \mu m$ long at $\times 40$ magnification. a to f: cellular areas. $\mathbf{g}$ to $\mathbf{i}$ : degenerative and necrotic areas. a and $\mathbf{g}$ : hematoxylin-eosin staining. NKTCL cells in the cellular areas (a) are positive for TIA1 (b) and CD56 (c) and show signals of EBER-1 ISH (d). Rare cleaved caspase-3-positive lymphoma cells were observed in cellular areas (e) and in degenerative and necrotic areas (h). The NKTCL cells expressed survivin (f and i). Necrosis in NKTCL was not due to apoptosis suppressed by neoplastic expression of survivin.

Table 5. Autophagy-related molecules and organella in nasopharyngeal lymphomas in representative cellular areas free from degeneration and necrosis

\begin{tabular}{lcrcccc}
\hline & & & \multicolumn{4}{c}{ Mean score evaluated value (S. D.) in IHC } \\
\cline { 5 - 7 } & EBV & N & Beclin-1 & LC3 & Mitochondria (AE-1) & Cathepsin D \\
\hline TML & & 28 & $2.0(1.2)$ & $2.6(1.0)$ & $2.3(0.9)$ & $1.1(0.9)$ \\
\hline NKTCL & - & $3.0(1.4)$ & $3.0(1.4)$ & $1.0(1.4)$ & $1.0(1.4)$ \\
NKTCL & + & 21 & $2.1(1.2)$ & $2.5(0.9)$ & $2.6(0.7)$ & $0.9(0.9)^{\# 1,2}$ \\
Cytotoxic-TML & + - or + & 3 & $1.0(1.0)$ & $3.0(1.0)$ & $2.0(1.0)$ & $2.0(-)^{\# 1,2}$ \\
E-NKTCL & + - or + & 2 & $1.7(0.4)$ & $2.7(1.2)$ & $1.3(1.5)$ & $1.2(1.0)$ \\
\hline BML & & 9 & $1.8(0.7)$ & $2.9(0.9)$ & $2.8(0.7)$ & $1.6(1.0)$ \\
\hline B-ML & - & 3 & $1.3(0.6)$ & $2.3(0.6)$ & $2.3(1.2)$ & $2.0(1.0)^{\# 2}$ \\
B-ML & + - & 3 & $1.7(0.6)$ & $3.0(1.0)$ & $3.0(-)$ & $1.7(1.2)$ \\
B-ML & + & 3 & $2.3(0.6)$ & $3.3(1.2)$ & $3.0(-)$ & $1.0(1.0)$ \\
\hline
\end{tabular}

TML, T/NK-cell neoplasm; BML, B-cell neoplasm; NKTCL, NK/T-cell lymphoma; Cytotoxic-TML, Cytotoxic T-cell lymphoma; E-NKTCL, Early NK/T-cell lymphoma; $\mathrm{EBV}^{+}$, Complete neoplastic expansion of EBV latent infection (Fig. 1); $\mathrm{EBV}^{+/}$, Incomplete neoplastic expansion of EBV latent infection (Fig. 1); $\mathrm{EBV}^{-}$, No EBV infection in lymphoma cells (Fig. 1).

Statistical evaluation: Evaluated scores in IHC of each antibody were tested in all combinations of two entities of lymphomas by Mann-Whitney's $\mathrm{U}$ test and in all combinations of more than three entities by Kruskal-Wallis test. In IHC of cathepsin D, only EBV NKTCL indicated significantly lower values than cytotoxic TML (\#1: Mann-Whitney's $U$ test, $p=0.0387$ ). Significantly lower values were also seen in the order of $E B V^{-} B M L$, cytotoxic TML and $\mathrm{EBV}^{+}$NKTCL (\#2: Kruskal-Wallis test, $\mathrm{p}=0.0396$ ), in that order.

way and the ATP-dependent $\mathrm{H}^{+}$pump are both concerned with these stages $[2,12,33]$. Their partial inhibition modulates the enhanced autophagy associated with ACD to the baseline level of autophagy [6], while the strong inhibition of the ATP-dependent $\mathrm{H}^{+}$pump induces ACD [33]. The enzymatic AR and supersensitive method [10] could only visualize a small amount of not-digested and probably complex form of beclin-1 [15, 32]. We succeeded in recog- 
with

EBV-NKTCL (1)

$\mathrm{EBV}^{+} \mathrm{NKTCL}$ without

peculiar necrosis $(2)$

$\mathrm{EBV}^{+} \mathrm{NKTCL}$

peculiar necrosis

Cellular area (3)

Beclin-1 (a)
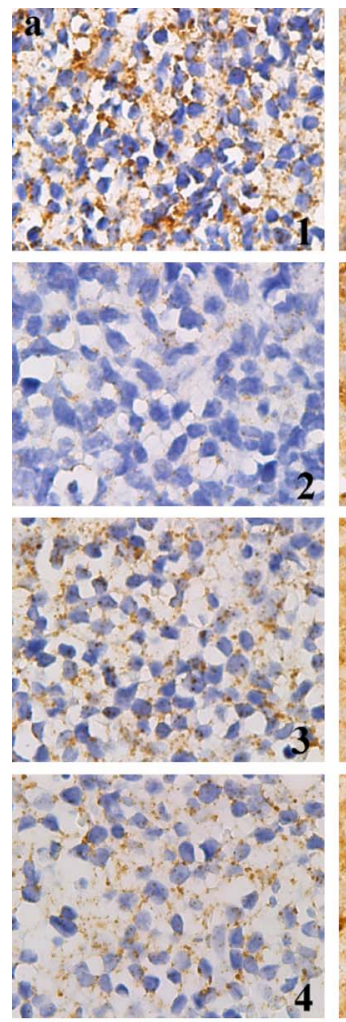

Degenerative area (4)

Peculiar necrosis $(5)$

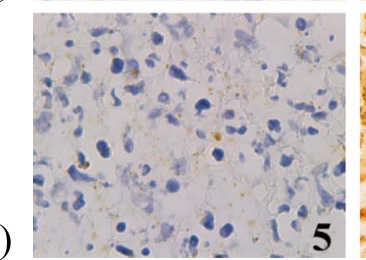

LC3 (b)
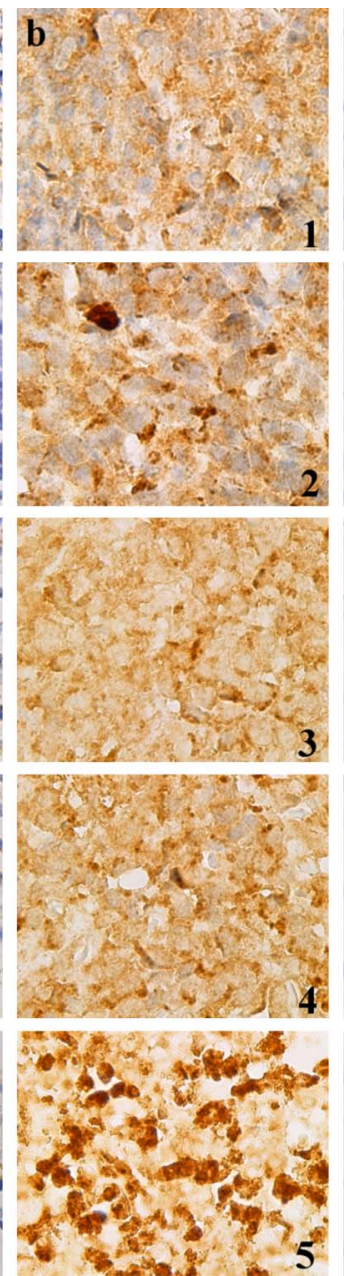

AE-1 (c)
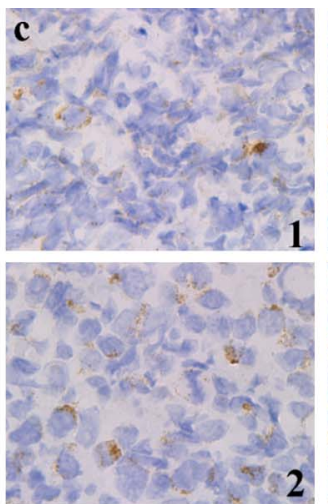

2

Cathepsin D (d)
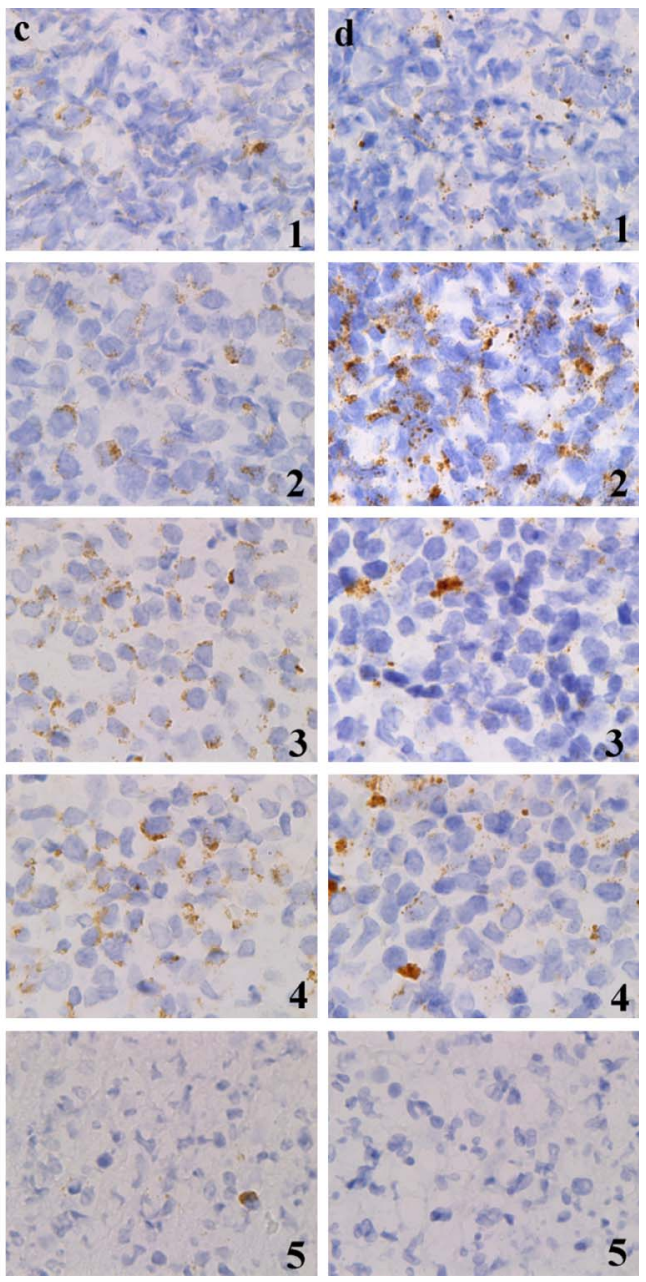

Fig. 4. Immunostaining of beclin-1, LC3, mitochondria (AE-1) and cathepsin D in NKTCL. 1: EBV- NKTCL. 2: EBV ${ }^{+} \mathrm{NKTCL}^{-}$free from degeneration. 3 to $\mathbf{5}$ : $\mathrm{EBV}^{+}$NKTCL revealing cellular (3), degenerative (4) and necrotic areas (5). a to d: Immunostaining of beclin-1 (a), LC3 (b), AE-1 (c) and cathepsin D (d). The long axis of all the microphotographs was $86 \mu \mathrm{m}$ long at $\times 100$ magnification. EBV $\mathrm{End} \mathrm{EBV}^{+}$ NKTCL cells in the cellular areas (1-3) showed expression of beclin-1 (a1 and a3), macrogranular staining with background microgranular staining (b1 and b3) or sporadic nuclear stain of LC3 (b2), aggregated mitochondria in many cells (c2 and $\mathbf{c 3}$ ) and expression of cathepsin D in lymphoma cells (d1 and d2). EBV ${ }^{+} \mathrm{NKTCL}$ with degeneration and necrosis showed gradually decreased expression of beclin-1 (a3 to a5), transition from macrogranular (b3 and b4) to nuclear stain of LC3 (b5), aggregated mitochondria labeled by AE-1 (c2, c3 and c4) and reduced expression of Cathepsin D (d3, $\mathbf{d 4}$ and $\mathbf{d 5})$. These findings indicated a baseline of autophagy with complete degradation of engulfed mitochondria in $\mathrm{EBV}^{-} \mathrm{NKTCL}$ cells (1), enhanced autophagy with sporadic ACD and highly engulfed mitochondria in $\mathrm{EBV}^{+} \mathrm{NKTCL}$ cells in the case free from degeneration (2), and enhanced autophagy with incomplete degradation of engulfed mitochondria ending in regional ACD caused by reduced expression of cathepsin $\mathrm{D}$ in $\mathrm{EBV}^{+} \mathrm{NKTCL}$ cells in the case with degeneration and necrosis (3 to $\left.\mathbf{5}\right)$.

nizing microgranular, macrogranular and dense perinuclear or nuclear immunostaining of anti-LC3 antibody in NKTCL cells employing heat $\mathrm{AR}$ independent from the $\mathrm{pH}$ of the solution [32] when ordinary AR-IHC of anti-LC3 antibody was reported to label LC3-II in the human pathology specimens $[5,26]$. These three patterns in the immunostaining of LC3 seemed to correspond to the cellular images of baseline autophagy, enhanced autophagy and ACD under a fluorescence microscope and an electron microscope. This study tried to detect mitochondria as macroautophagic targetorganella and to see first the engulfed and degraded mito- chondria in autophagosome and autolysosome by means of IHC of AE-1. Detecting beclin-1, LC3, aggregated mitochondria and cathepsin D by IHC, it became finally possible to monitor the condition of autophagy on sections of the archival pathology specimens.

We elucidated that NKTCL cells in the case free from degeneration showed sporadic distribution of ACD, as shown in Figure 4b2. The proliferation with sporadic ACD of the NKTCL cells in the case free from degeneration can be regarded to be that of the steady state of growth maintaining a mass of NKTCL cells with certain ratios of 
Beclin-1 (a)

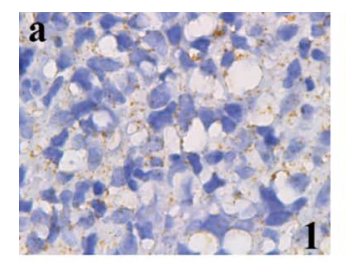

EBV- DLBCL cells in the microabscess (2)

\section{$\mathrm{EBV}^{+}$DLBCL with peculiar necrosis}

\section{Cellular area (3)}

Peculiar necrosis (4)

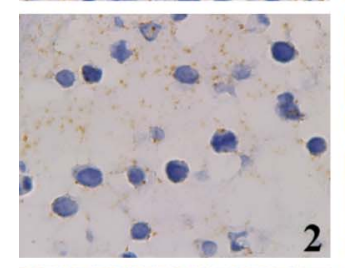

LC3 (b)

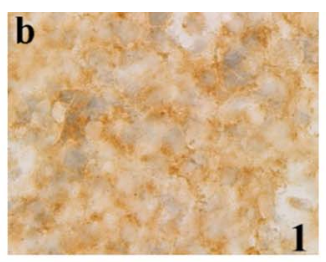

AE-1 (c)

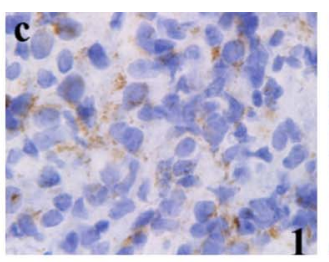

Cathepsin D (d)
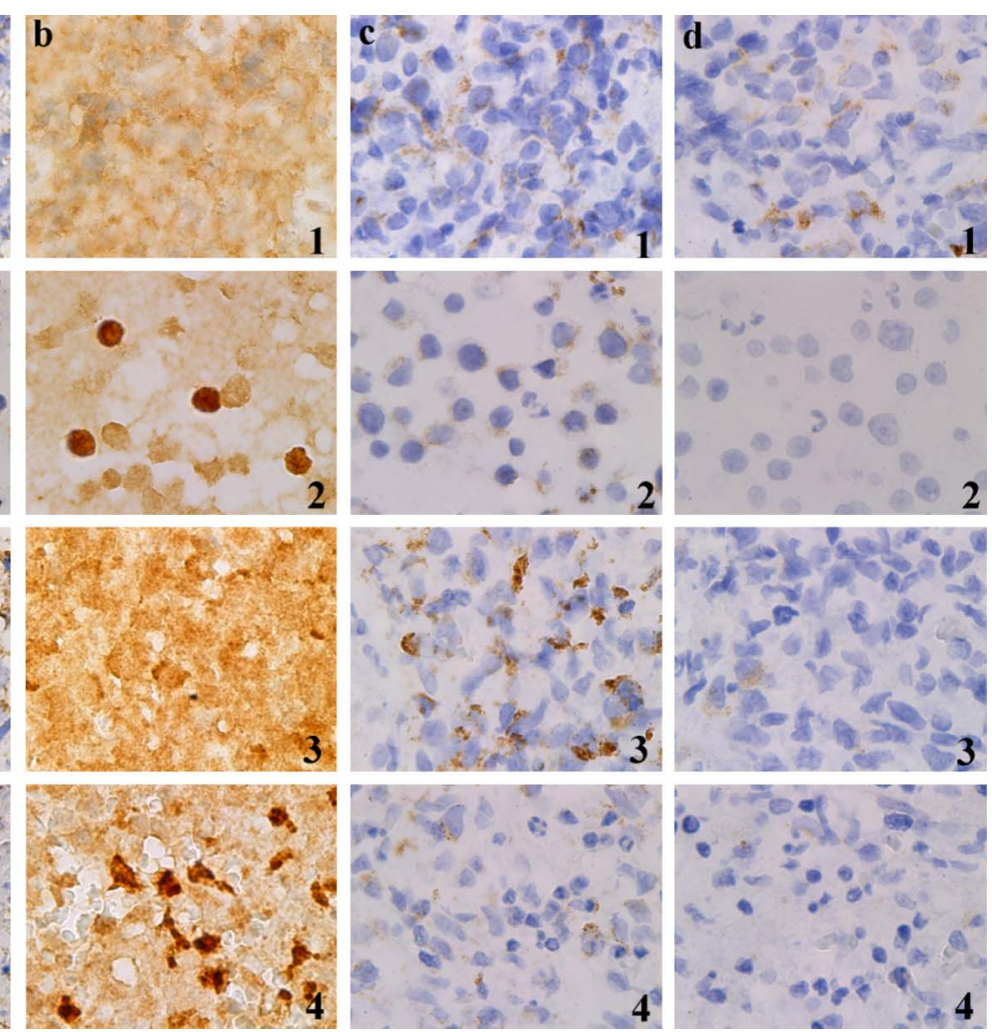

Fig. 5. Immunostaining of beclin-1, LC3, AE-1 and cathepsin D in BML. 1 and 2: EBV- BML with an intraepithelial microabscess (2). 3 and 4: $\mathrm{EBV}^{+} \mathrm{BML}$ revealing sporadic tiny necrosis (4). a) Immunostaining of beclin-1. b) Immunostaining of LC3. c) Immunostaining of AE-1. d) Immunostaining of Cathepsin D. The long axis of all the microphotographs was $86 \mu \mathrm{m}$ long at $\times 100$ magnification. EBV $\mathrm{BML}^{-}$cells showed weak expression of beclin-1 (a1), macrogranular immunostaining of LC3 (b1), aggregated mitochondria (c1) and expression of cathepsin D (d1) when the lymphoma cells in the microabscess revealed little expression of beclin-1 (a2), nucleus-like staining of LC3 (b2), aggregated mitochondria (c2) and no expression of cathepsin D (d2), suggesting a baseline of autophagy in EBV ${ }^{-} \mathrm{BML}^{\mathrm{and}} \mathrm{ACD}$ with incomplete degradation of mitochondria and no expression of cathepsin $\mathrm{D}$ in $\mathrm{EBV}^{-} \mathrm{BML}$ cells in starvation in the microabscess. EBV ${ }^{+} \mathrm{BML}$ cells showed expression of beclin-1 (a3), micro- and macrogranular stain of LC3 (b3), aggregated mitochondria labeled by AE-1 (c3) and no expression of cathepsin D (d3) when some lymphoma cells in a tiny focus of necrosis showed little expression of beclin-1 (a4), some nuclear staining of LC3 in the background of its micro- and macrogranular stain (b4), scant aggregated mitochondria (c4) and no expression of cathepsin D (d4), suggesting enhanced autophagy with incomplete degradation of mitochondria and no expression of cathepsin $\mathrm{D}_{\text {in }} \mathrm{EBV}^{+} \mathrm{BML}_{\mathrm{M}}$ cells and ending in regional ACD.

proliferating cells and dying cells because of PCD [18] and possibly that of the steady state of growth of pancreatic beta cells in pancreas duodenal homeobox-1 (pdx1) deficient mouse maintaining a smaller mass and a smaller number of Ki67 antigen positive cells than in the normal mouse and beclin-1 knock-out mouse or pdx1 and beclin-1 double knock-out mouse [6].

Autophagy is enhanced in starvation. $\mathrm{EBV}^{-} \mathrm{BML}$ cells in an intraepithelial microabscess reveal a hallmark of ACD (Fig. 5b2) in starvation and no immunostaining of cathepsin D (Fig. 5d2), indicating that a halt of cathepsin D synthesis preceded ACD, as suggested first by Uchiyama [30]. The cells would be filled with autophagosomes and autolysosomes and would die because of lack of energy and nutrient supply from autophagy when the contents of autolysosomes were not digested completely, as indicated by the presence of aggregated mitochondria in degenerative

\section{$\mathrm{EBV}^{-}$BML cells (Fig. 5c2).}

We found that the peculiar necrosis in NKTCL was of grouped LC3-densely labeled cells (ACD) in the illdefined areas [32] (regional ACD). The peculiar necrosis was noted in $\mathrm{EBV}^{+} \mathrm{NKTCL}, \mathrm{EBV}^{+}$Cytotoxic-TML and $\mathrm{EBV}^{+} \mathrm{BML}$ (Table 6), suggesting that the regional ACD was induced under EBV infection [32] when the lymphoma cells showed complete neoplastic expansion of EBV latent infection (Fig. 1) [32].

The EBV infection in $\mathrm{EBV}^{+}$NKTCL is of Latency II [28] expressing a quite large numbered copies of EBER-1, small numbered copies of BamH1-A rightward transcripts (BARTs), EBV nuclear antigen-1 (EBNA-1) and Latent membrane proteins (LMPs). Viral products, including EBNA-1, are processed by autophagy and are presented on cell surface with HLA class II molecules [23]. EBER-1 originated from $\mathrm{EBV}^{+}$cells is recognized as double-stranded 
Table 6. Autophagy-related molecules and organella in nasopharyngeal lymphomas in areas with degeneration and necrosis

\begin{tabular}{|c|c|c|c|c|c|c|c|c|c|c|c|c|c|}
\hline & \multirow[b]{3}{*}{$\mathrm{n}$} & \multicolumn{12}{|c|}{ Score value or Mean score value (S.D.) of IHC } \\
\hline & & \multicolumn{3}{|c|}{ Beclin-1 } & \multicolumn{3}{|c|}{ LC3 } & \multicolumn{3}{|c|}{ Mitochondria (AE-1) } & \multicolumn{3}{|c|}{ Cathepsin D } \\
\hline & & $\mathrm{C}$ & $\mathrm{D}$ & $\mathrm{N}$ & $\mathrm{C}$ & $\mathrm{D}$ & $\mathrm{N}$ & $\mathrm{C}$ & $\mathrm{D}$ & $\mathrm{N}$ & $\mathrm{C}$ & $\mathrm{D}$ & $\mathrm{N}$ \\
\hline \multicolumn{14}{|l|}{$\mathrm{EBV}^{-} \mathrm{BML}$} \\
\hline+ microabscess & 1 & 1 & 1 & & 2 & 4 & & 3 & 3 & & 3 & 0 & \\
\hline $\mathrm{EBV}^{+} \mathrm{BML}$ & 2 & $\begin{array}{c}2.5 \\
(0.7)\end{array}$ & & & $\begin{array}{c}4 \\
(-)\end{array}$ & & & $\stackrel{3}{(-)}$ & & & $\begin{array}{c}1.5 \\
(0.7)\end{array}$ & & \\
\hline+ necrosis & 1 & 2 & 1 & 1 & 2 & 2 & 4 & 3 & 1 & 1 & 0 & 0 & 0 \\
\hline Cytotoxic-TML & $1 *$ & 2 & & & 4 & & & 2 & & & 2 & & \\
\hline+ necrosis & $2 * *$ & $\begin{array}{c}0.5 \\
(0.7)\end{array}$ & $\begin{array}{c}0.5 \\
(0.7)\end{array}$ & $\stackrel{0}{(-)}$ & $\begin{array}{c}2.5 \\
(0.7)\end{array}$ & $\begin{array}{c}3 \\
(1.4)\end{array}$ & $\begin{array}{c}4.5 \\
(0.7)\end{array}$ & $\begin{array}{l}2.0 \\
(1.4)\end{array}$ & $\begin{array}{c}2.0 \\
(1.4)\end{array}$ & $\begin{array}{c}1 \\
(1.4)\end{array}$ & $\stackrel{2}{-})$ & $\begin{array}{c}1.5 \\
(0.7)\end{array}$ & $\begin{array}{c}1.0 \\
(1.4)\end{array}$ \\
\hline $\mathrm{EBV}^{+} \mathrm{NKTCL}$ cellular areas & 4 & $\begin{array}{c}2.0 \\
(1.8)\end{array}$ & & & $\begin{array}{c}3.3 \\
(0.6) \\
\# 1,3\end{array}$ & & & $\begin{array}{c}2.0 \\
(\underset{\# 4}{\# 4})\end{array}$ & & & $\begin{array}{c}1.5 \\
(1.3)\end{array}$ & & \\
\hline+ degeneration & 6 & $\begin{array}{l}1.8 \\
(0.8)\end{array}$ & $\begin{array}{c}1.3 \\
(0.8)\end{array}$ & & $\begin{array}{c}3.0 \\
(0.6) \\
\# 1,2,5\end{array}$ & $(\underset{\# 5}{4.0})$ & & $\begin{array}{c}2.5 \\
(0.8) \\
\# 6\end{array}$ & $\begin{array}{c}1.3 \\
\left(\begin{array}{c}0.8) \\
\# 6\end{array}\right.\end{array}$ & & $\begin{array}{c}1.2 \\
(0.8)\end{array}$ & $\begin{array}{c}0.7 \\
(0.8)\end{array}$ & \\
\hline+ degeneration and necrosis & 11 & $\begin{array}{c}2.4 \\
(1.1) \\
\# 7\end{array}$ & $\begin{array}{c}2.1 \\
(1.0) \\
\# 8\end{array}$ & $\begin{array}{c}0.9 \\
(0.7) \\
\sharp 7,8\end{array}$ & $\begin{array}{c}1.9 \\
(0.7) \\
\# 1,2,3,9,10\end{array}$ & $\begin{array}{c}3.1 \\
(0.8) \\
\# 9,11\end{array}$ & $\begin{array}{l}4.0 \\
(0.5) \\
\# 10,11\end{array}$ & $\begin{array}{c}2.8 \\
(0.4) \\
\# 4,12\end{array}$ & $\begin{array}{c}2.8 \\
(0.4) \\
\# 13\end{array}$ & $\begin{array}{c}1.4 \\
(0.9) \\
\# 12,13\end{array}$ & $\begin{array}{c}0.5 \\
(0.7) \\
\# 14\end{array}$ & $\begin{array}{c}0.5 \\
(0.5)\end{array}$ & $\begin{array}{c}0.2 \\
(0.4) \\
\# 14\end{array}$ \\
\hline
\end{tabular}

n, Number of cases; C, Cellular area; D, Degenerative area; N, Necrotic area; EBV- BML+microabscess, EBV infection-free BML revealing intraepithelial microabscess; +necrosis, lymphoma revealing foci of necrosis; +degeneration, lymphoma revealing degeneration; +degeneration and necrosis, lymphoma revealing degeneration and necrosis; Cytotoxic-TML 1*, one $\mathrm{EBV}^{+/-}$case; Cytotoxic-TML+necrosis $2^{* *}$, two EBV ${ }^{+}$ cases.

Statistical evaluation: NKTCL cells in the cellular area indicated significant gradual decrease in LC-3 score in the groups with cellular, degenerative and necrotic areas $\left({ }^{\# 1}\right.$ : Kruskal-Wallis test, $p=0.0036,{ }^{\# 2,3}$ : Mann-Whitney's U test, $\left.\# 2 \mathrm{p}=0.0103, \# 3 \mathrm{p}=0.0062\right)$ and significant increase of Mitochondria (AE-1) score from the group of cellular area to the group with degenerative and necrotic areas (\#4: Mann-Whitney's U test, $\mathrm{p}=0.0335$ ). NKTCL cells in the group with degenerative and necrotic areas indicated significant increase in LC3 score (\#5: Wilcoxon signed-ranks test, $\# 5 \mathrm{p}=0.0339)$ and significant decrease in Mitochondria (AE-1) score ( ${ }^{* 6}$ : Wilcoxon signed-ranks test, $\left.\mathrm{p}=0.0384\right)$. NKTCL cells in the group with degenerative and necrotic areas indicated significant decrease of beclin-1 score from groups with the cellular to necrotic areas ( $\$ 7,8$ : Wilcoxon signed-ranks test, $\# 7 \mathrm{p}=0.0041$, \#8 p=0.0030), significant increase in LC3 score $\left({ }^{\#-11}\right.$. Wilcoxon signed-ranks test, $\# 9 \mathrm{p}=0.0035$, \#10 p=0.0022, $\# 11 \mathrm{p}=0.0041$ ), significant decrease in Mitochondria (AE-1) score ( $\# 12,13$ : Wilcoxon signed-ranks test, \#12 $\mathrm{p}=0.0076$, \#13 $\mathrm{p}=0.005)$ and significant decrease in cathepsin D score $\left({ }^{\# 14}\right.$ : Wilcoxon signed-ranks test, $\left.\mathrm{p}=0.0455\right)$.

RNA by Toll-like receptor 3 and retinoic acid inducible gene-1 in the endosome (Fig. 6) and induces cellular antiviral innate immunity responses such as production of type 1 interferon and secretion of proinflammatory cytokines in infectious mononucleosis, chronic active EBV infection and EBV-associated hemophagocytic lymphohistiocytosis [13]. However, innate immunity has not yet been reported to play a role in histogenesis of $\mathrm{EBV}^{+}$NKTCL with symbiotic $\mathrm{CD}^{204^{+}}$macrophages forming a meshwork in the background [32]. In $\mathrm{EBV}^{+}$lymphoblastoid cell line and $\mathrm{EBV}^{+}$ Burkitt's lymphoma cell line, low level of expression of LMP-1 maintained B-cell growth and enhanced autophagy when high expression level of LMP-1 induced cytostasis and transient inhibition of protein synthesis [19]. The stimuli from a low expression level of LMP-1 [16] with suppressed expression of Bcl-2 [32] has an indirect effect on beclin-1 to form a vesicle nucleation complex (Fig. 6) and enhance autophagy in $\mathrm{EBV}^{+} \mathrm{NKTCL}$ free from degeneration and necrosis. Autophagy suppressed hypersensitive response inducing bystander tissue necrosis in tobacco mosaic virus infection [19].

$\mathrm{EBV}^{+}$NKTCL free from the degeneration showed enhanced autophagy in table 6, although the middle score of beclin-1 (Fig. 4a2, Table 6) suggested possibly directly enhanced elongation of autophagophore labeled by LC3 rather than the effect of beclin-1 under LMP-1 mentioned above, indicated by significantly high LC3 score (Fig. 4b2), significantly low aggregated mitochondria score (Fig. 4c2) and high cathepsin D score (Fig. $4 \mathrm{~d} 2$ ). $\mathrm{EBV}^{+}$NKTCL cells in the cellular areas in the cases with degeneration and necrosis showed suppressed autophagy as indicated by the likely compensatory high beclin-1 score (Fig. 4a3), significantly low LC3 score (Fig. 4b3), significantly high aggregated mitochondria score (Fig. 4c3) and significantly low cathepsin D score (Fig. 4d3) in Table 6.

However, the low synthesis of lysosomal enzymes cannot be explained by the transient low synthesis of proteins under the high level of LMP-1 expression. Protein kinase RNA regulated (PKR), induced by interferon- $\alpha$ under viral infection but usually suppressed by binding with EBER-1 [21, 22], can suppress protein synthesis. Depletion of a small amount of EBER-1 in cytoplasm under enhanced autophagy may reactivate PKR and induce low synthesis of proteins such as that of cathepsin D in the $\mathrm{EBV}^{+}$NKTCL 


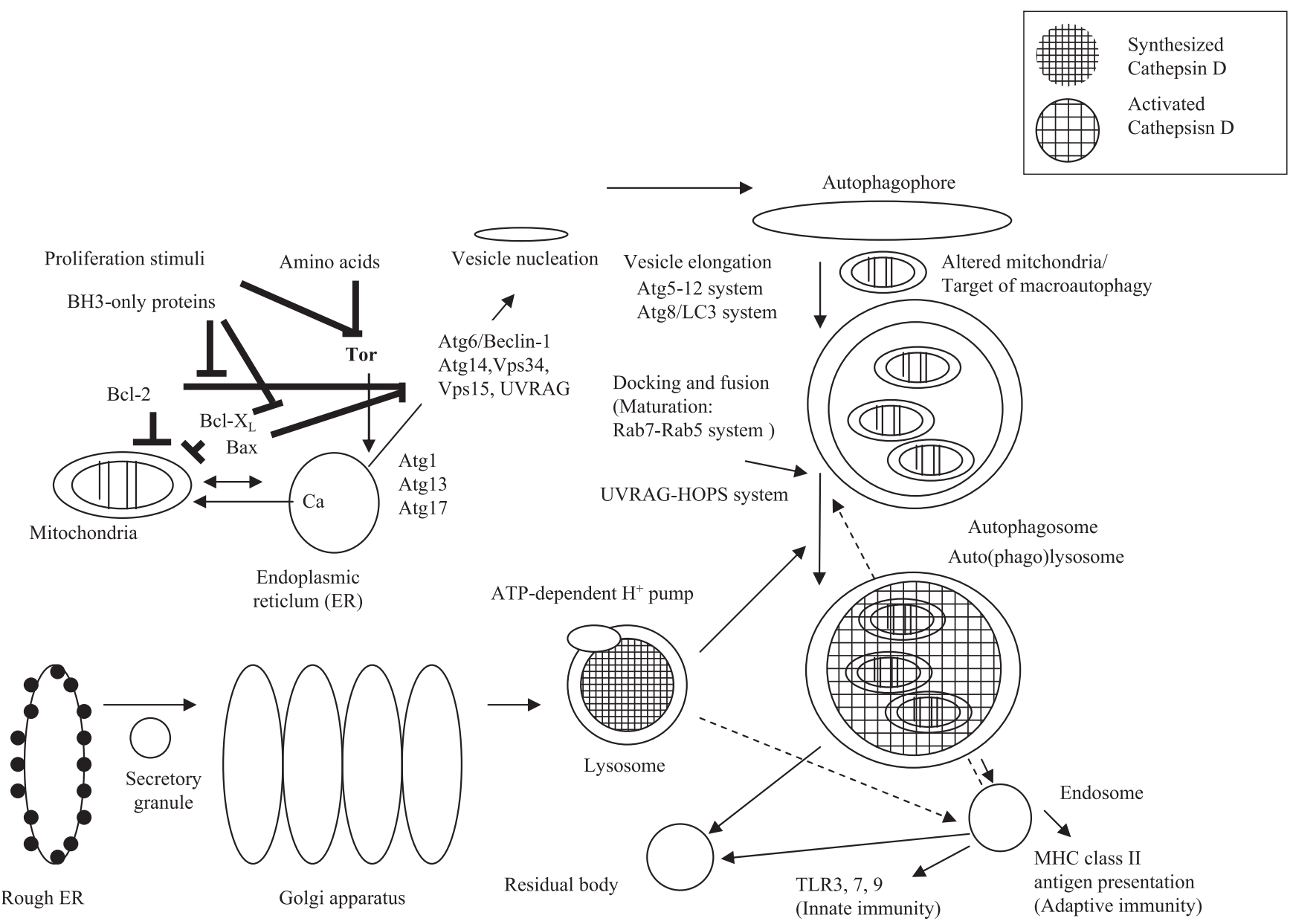

Fig. 6. Schematic diagram of molecular mechanism of autophagy with synthesis of cathepsin D. Autophagy comprises an initiating stage from Tor to a complex formation that includes Atg1 in the endoplasmic reticulum; a vesicle nucleation stage with a complex including Atg6/beclin-1; vesicle elongation and autophagosome formation stage with membrane-bound LC3 and engulfing target organella; and an auto(phago)lysosome formation stage with activation of lysosome enzymes including cathepsin D. On the other hand, cathepsin D is synthesized in the rough endoplasmic reticulum, develops by adding glyocoproteins to itself in the Golgi apparatus and is stored in the lysosomes when the ATP-dependent $\mathrm{H}^{+}$pump adds acidity to the lysosome content to activate cathepsin $\mathrm{D}$. Some autolysosomes become endosomes when there is a connection to innate and adaptive immunity, and autolysosomes finally become residual bodies. The pharmacological functional analysis of autophagy is made possible by the inhibition of PI3K sending signals to Tor (the PI3K-Tor pathway) and of the ATP-dependent $\mathrm{H}^{+}$pump adding acicidity to the lysosomal and autolysosomal contents (the activation of cathepsin D). Each or combined failures in the fusion of autophagosome and lysosome, in the degradation of content in the autolysosome, and in the activation of cathepsin D by ATP-dependent $\mathrm{H}^{+}$pump induce autophagic cell death (ACD) with enlarged autophagosomes and autolysosomes.

cells in the cellular areas in the cases with degeneration and necrosis (Fig. 4d3, Table 6) as well as in the $\mathrm{EBV}^{+}$ BML cells in the cellular areas (Fig. 5d3, Table 6). EBV ${ }^{+}$ NKTCL with degeneration and necrosis suggested that advanced autophagy with low protein synthesis induces ACD of lymphoma cells in the regional areas (Table 6) probably by the destruction of symbiotic growth with $\mathrm{CD}_{204^{+}}$macrophages [32]. Tiny foci of ACD in $\mathrm{EBV}^{+} \mathrm{BML}$ unassociating with symbiotic CD204 $4^{+}$macrophages were also characteristic of which would be categorized as lymphomatoid granulomatosis in the WHO classification [14].

This study indicated that the IHC of beclin-1. LC3, mitochondria and cathepsin D could monitor the status of autophagy in nasopharyngeal lymphomas. It was also shown that ACD is caused by enhanced autophagy with failures in lysosomes and autolysosomes when apoptosis is suppressed and is not the result of molecular signaling in autophagy. Finally, in $\mathrm{EBV}^{+}$NKTCL, enhanced autophagy and reduced expression of cathepsin D induced peculiar necrosis of the regional ACD.

\section{Acknowledgments}

The authors wish to thank Prof. Noboru Mizushima (Tokyo Medical and Dental University) for information about LC3, Prof. Katsuyuki Aozasa (Osaka University) 
and Prof. Emeritus Eiichi Sato and Prof. Shuji Izumo (Kagoshima University) for their helpful suggestions, and Dr. Hiroshi Shirahama, Dr. Yukie Tashiro, Mr. Keishi Tokunaga and Ms. Yasuko Shinmura of Imakiire General Hospital for preparing paraffin sections and for in-situ hybridization of EBER-1. This study was supported in part by Grant-in-Aid from Japan Society for the Promotion of Science (JSPS) (19406007B, to Hasui K).

\section{References}

1. Ambrosini, G., Adida, C. and Altieri, D. C. (1997) A novel antiapoptosis gene, survivin, expressed in cancer and lymphoma. Nat. Med. 3; 917-921

2. Caro, L. H., Plomp, P. J., Wolvetang, E. J., Kerkhof, C. and Meijer, A. J. (1988) 3-Methyladenine, an inhibitor of autophagy, has multiple effects on metabolism. Eur. J. Biochem. 175; 325329.

3. Delgado, M., Singh, S., de Haro, S., Master, S., Ponpuak, M., Dinkins, C., Ornatowski, W., Vergne, I. and Deretic, V. (2009) Autophagy and pattern recognition receptors in innate immunity. Immunol. Rev. 227; 189-202.

4. Deretic, V. (2005) Autophagy in innate and adaptive immunity. Trends Immunol. 26; 523-528

5. Fujii, S., Mitsunaga, S., Yamazaki, M., Hasebe, T., Ishii, G., Kojima, M., Kinoshita, T., Ueno, T., Esumi, H. and Ochiai, A. (2008) Autophagy is activated in pancreatic cancer cells and correlates with poor patient outcome. Cancer Sci. 99; 1813-1819.

6. Fujimoto, K., Hanson, P. T., Tran, H., Ford, E. L., Han, Z., Johnson, J. D., Robert, E. Schmidt., Green, K. G., Wice, B. M. and Polonsky, K. S. (2009) Autophagy regulates pancreatic beta cell death in response to Pdx1 deficiency and nutrient deprivation. J. Biol. Chem. 284; 27664-27673.

7. García, J. F., Mollejo, M., Fraga, M., Forteza, J., Muniesa, J. A., Pérez-Guillermo, M., Pérez-Seoane, C., Rivera, T., Ortega, P. and Piris, M. A. (2005) Large B-cell lymphoma with Hodgkin's features. Histopathology 47; 101-110.

8. Gown, A. M. and Willingham, M. C. (2002) Improved detection of apoptotic cells in archival paraffin sections: immunohistochemistry using antibodies to cleaved caspase 3. J. Histochem. Cytochem. 50; 449-454.

9. Harabuchi, Y., Yamanaka, N., Kataura, A., Imai, S., Kinoshita, T., Mizuno, F. and Osato, T. (1990) Epstein-Barr virus in nasal T-cell lymphomas in patients with lethal midline granuloma. Lancet $335 ; 128-130$.

10. Hasui, K. and Murata, F. (2005) A new simplified catalyzed signal amplification system for minimizing non-specific staining in tissues with supersensitive immunohistochemistry. Arch. Histol. Cytol. 68; 1-17.

11. Hino, R., Uozaki, H., Inoue, Y., Shintani, Y., Ushiki, T., Sakatani, T., Takada, K. and Fukayama, M. (2008) Survival advantage of EBV-associated gastric carcinoma: Survivin up-regulation by viral latent membrane protein 2A. Cancer Res. 68; 427-435.

12. Itakura, E. and Mizushima, N. (2010) Characterization of autophagosome formation site by a hierarchical analysis of mammalin Atg proteins. Autophagy 66; 764-776.

13. Iwakiri, D., Zhou, L., Samanta, M., Matsumoto, M., Ebihara, T., Seya, T., Imai, S., Fujieda, M., Kawa, K. and Takada, K. (2009) Epstein-Barr virus (EBV)-encoded small RNA is released from EBV-infected cells and activates signaling from Toll-like receptor 3. J. Exp. Med. 206; 2091-2099.

14. Jaffe, E. S., Harris, N. L., Stein, H. and Vardiman, J. W. (eds) (2001) World Health Organization classification of Tumors, Pathology \& Genetics, Tumors of Haematopoietic and lymphoid tissues. International Agency for Research on Cancer (IARC) Press, Lyon.

15. Kato, K., Hasui, K., Wang, J., Kawano, Y., Aikou, T. and Murata, F. (2008) Homeostatic mass control in gastric non-neoplastic epithelia under infection of Helicobacter pylori: An immuno- histochemical analysis of cell growth, stem cells and programmed cell death. Acta Histochem. Cytochem. 41; 23-38.

16. Lee, D. Y. and Sugden, B. (2008) The latent membrane protein-1 oncogene modifies B-cell physiology by regulating autophagy. Oncogene 27; 2833-2842.

17. Levine, B. and Kroemer, G. (2008) Autophagy in the pathogenesis of disease. Cell 132; 27-42.

18. Li, A., Hasui, K., Yonezawa, S., Shirahama, H., Kitajima, S. and Sato, E. (2000) Immunohistochemical estimation of in-situ cell cycle time in neoplastic epithelial cells in human large intestine: a new cell proliferation index. Hum. Cell 13; 117-125.

19. Liu, Y., Schiff, M., Czymmek, K., Tallóczy, Z., Levine, B. and Dinesh-Kumar, S. P. (2005) Autophagy regulates programmed cell death during the plant innate immune response. Cell 121; 567-577.

20. McBride, P. (1897) Photographs of a case of rapid destruction of the nose \& face. Laryngol. 12; 64-66.

21. Nanbo, A., Inoue, K., Adachi-Takasawa, K. and Takada, K. (2002) Epstein-Barr virus RNA confers resistance to interferonalpha-induced apoptosis in Burkitt's lymphoma. EMBO J. 21; 954-965.

22. Nanbo, A., Yoshiyama, H. and Takada, K. (2005) Epstein-Barr virus-encoded poly(A)-RNA confers resistance to apoptosis mediated through Fas by blocking the PKR pathway in human epithelial intestine 407 cells. J. Virol. 79; 12280-12285.

23. Paludan, C., Schmid, D., Landthaler, M., Vockerodt, M., Kube, D., Tuschl, T. and Münz, C. (2005) Endogenous MHC class II processing of a viral nuclear antigen after autophagy. Science 307; 593-596

24. Pattingre, S., Tassa, A., Qu, X., Garutl, R., Liang, X. H., Mizushima, N., Packer, M., Schneider, M. D. and Levine, B. (2005) Bcl-2 antiapoptotic proteins inhibit Beclin-1-dependent autophagy. Cell 122; 927-939.

25. Peplowska, K., Cabrera, M. and Ungermann, C. (2008) UVRAG reveals its second nature. Nat. Cell Biol. 10; 759-761.

26. Sato, K., Tsuchihara, K., Fujii, S., Sugiyama, M., Goya, T., Atomi, Y., Ueno, T., Ochiai, A. and Esumi, H. (2007) Autophagy is activated in colorectal cancer cells and contributes to the tolerance to nutrient deprivation. Cancer Res. 67; 9677-9684.

27. Shoji-Kawata, S. and Levine, B. (2009) Autophagy, antiviral immunity, and viral countermeasures. Biochim. Biophys. Acta $1793 ; 1478-1484$

28. Takahara, M., Kishibe, K., Bandoh, N., Nonaka, S. and Harabuchi, Y. (2004) P53, N- and K-Ras, and beta-catenin gene mutations and prognostic factors in nasal NK/T-cell lymphoma from Hokkaido, Japan. Hum. Pathol. 35; 86-95.

29. Tokunaga, M., Land, C. E., Uemura, Y., Tokudome, T., Tanaka, S. and Sato, E. (1993) Epstein-Barr virus in gastric carcinoma. Am. J. Pathol. 143; 1250-1254.

30. Uchiyama, Y. (2001) Autophagic cell death and its execution by lysosomal cathepsins. Arch. Histol. Cytol. 64; 233-246.

31. Wagner, M., Schmelz, K., Dörken, B. and Tamm, I. (2008) Epigenetic and genetic analysis of the survivin promoter in acute myeloid leukemia. Leuk. Res. 32; 1054-1060.

32. Wang, J., Hasui, K., Jia, X. S., Matsuyama, T. and Eizuru, Y. (2009) Possible role for external environmental stimuli in nasopharyngeal NK/T-cell lymphomas in the northeast of China with EBV infection-related autophagic cell death: A pathoepidemiological analysis. J. Clin. Exp. Hematop. 49; 97-108.

33. Yamamoto, A., Tagawa, Y., Yoshimori, T., Moriyama, Y., Masaki, R. and Tashiro, Y. (1998) Bafilomycin Al prevents maturation of autophagic vacuoles by inhibiting fusion between autophagosomes and lysosomes in rat hepatoma cell line, H-4-II-E cells. Cell Struct. Funct. 23; 33-42.

This is an open access article distributed under the Creative Commons Attribution License, which permits unrestricted use, distribution, and reproduction in any medium, provided the original work is properly cited. 